\title{
Indoor Air Quality in Central Appalachia Homes Impacted by Wood and Coal Use
}

\author{
Laura M. Paulin¹, D’Ann Williams², Charles Oberweiser ${ }^{3}$, Gregory B. Diette ${ }^{1}$, Patrick N. Breysse ${ }^{2}$, \\ Meredith M. McCormack ${ }^{1}$, Elizabeth C. Matsui ${ }^{4}$, Roger Peng $^{5}$, Tricia A. Metts ${ }^{6}$, Nadia N. Hansel $^{1}$ \\ ${ }^{1}$ Division of Pulmonary and Critical Care, Department of Medicine, Johns Hopkins School of Medicine, Baltimore, USA; ${ }^{2}$ Division \\ of Environmental Health Engineering, Department of Environmental Health Sciences, Johns Hopkins Bloomberg School of Public \\ Health, Baltimore, USA; ${ }^{3}$ Appalachia Service Project, Johnson City, USA; ${ }^{4}$ Division of Allergy and Immunology, Department of \\ Pediatrics, Johns Hopkins School of Medicine, Baltimore, USA; ${ }^{5}$ Department of Biostatistics, Johns Hopkins Bloomberg School of \\ Public Health, Baltimore, USA; ${ }^{6}$ Department of Environmental Health, East Tennessee State University College of Public Health, \\ Johnson City, USA. \\ Email: lpaulin1@jhmi.edu
}

Received November $15^{\text {th }}, 2012$; revised December $12^{\text {th }}, 2012$; accepted January $8^{\text {th }}, 2013$

\begin{abstract}
Though the high prevalence of biomass fuel use in the developing world is widely known, the use of burning biomass for cooking and heating in the developed world is under-recognized. Combustion materials including coal and wood are also used for heating in some areas of the United States. We conducted a pilot study to assess the feasibility of conducting indoor environmental monitoring in rural Appalachia. We sought to explore the type of biomass being used for home heating and its impact upon indoor air quality in non-heating and heating seasons. Residential indoor air monitoring for particulate matter (PM) and nitrogen dioxide $\left(\mathrm{NO}_{2}\right)$ was conducted in Lee County, Virginia. Homes had evidence of poor indoor air quality with high concentrations of indoor PM and a large burden of cigarette smoking. Further characterization of indoor combustion material use in this region to determine the health impacts associated with such exposures is warranted.
\end{abstract}

Keywords: Indoor Air Pollution; Biomass; Rural Environment

\section{Introduction}

Over half of the world's population relies on open burning of biomass fuels for cooking and heating [1]. The World Health Organization estimates that emissions from cook stoves are one of the top five threats to public health in poor, developing countries [2]. Burning biomass significantly alters the indoor environment by increasing levels of pollutants, including particulate matter (PM), which are linked to poor health outcomes [2-6]. Although biomass fuels are generally perceived to be a public health problem in developing countries, indoor combustion materials, including coal and wood, are also used as primary or secondary heating fuels in many communities in the United States.

In some areas of Central Appalachia, it is estimated that up to $30 \%$ of homes use wood and/or coal for primary heating [7]. Cultural differences and housing characteristics may alter the impact of fuel use on the concentration of indoor pollutants, as pollutant burden is dependent on episodic characteristics of fuel burning and microenvironments around the fuel, including ventilation
[8-10]. Consequently, the effect of coal and wood use on indoor pollutant concentrations in developed nations may differ from that observed in developing countries.

The impact of wood and/or coal burning on the indoor environment in Appalachia is not well described, and we are unaware of any recent studies that have conducted direct indoor air monitoring in residential settings in this region. To address this gap in knowledge, we designed a pilot study to assess the feasibility of conducting indoor environmental monitoring in rural Appalachia, and to explore the type of fuel being used for home heating and its impact upon indoor air quality in non-heating and heating seasons.

\section{Methods}

\subsection{Study Design}

Recruitment began in July of 2011 and ended in December 2011. Homes in Lee County, Virginia were recruited in partnership with the Appalachia Service Project (ASP), a faith-based, non-profit Christian organization that provides free home repair to needy families in the Central 
Appalachia region. Families receiving services from ASP were notified of the study by ASP staff and contacted by study personnel to arrange for sampling. Owner-occupied homes with adequate electricity and an English-speaking homeowner able to provide informed consent were eligible. The study was reviewed and approved by the Johns Hopkins Institutional Review Board. Written informed consent was obtained from home owners.

\subsection{Environmental Sampling}

Assessments were conducted during a warm weather season (Visit 1, August 2011) and cold weather season after indoor home heating had commenced (Visit 2, December 2011). Each visit consisted of home inspection and indoor air monitoring including sampling for $\mathrm{PM}_{2.5}$ and coarse $\mathrm{PM}\left(\mathrm{PM}_{2.5-10}\right.$; calculated by subtracting $\mathrm{PM}_{2.5}$ from $\left.\mathrm{PM}_{10}\right)$, air nicotine, and nitrogen dioxide $\left(\mathrm{NO}_{2}\right)$ in the main living area of the home. Air sampling was conducted in the main living area of the home over a sampling period of four days. Continuous air sampling for particulate matter was conducted in the active mode, using $\mathrm{PM}_{10}$ and $\mathrm{PM}_{2.5} 4 \mathrm{~L} / \mathrm{min}$ impactors (MSP Corp, St. Paul, MN) loaded with $37 \mathrm{~mm}, 2.0$ um pore size, Teflon polytetrafluoroethylene membrane filters with polypropylene support rings (Pall Corporation, Ann Arbor, MI) and BGI 400S sampling pumps (BGI, Inc., Waltham, $\mathrm{MA})$. Four-day integrated $\mathrm{NO}_{2}$ samples were collected using a passive sampler (Ogawa \& Co., Pompano Beach, FL) loaded with filters coated with triethanolamine (TEA). In the presence of a color reagent, $\mathrm{NO}_{2}$ and TEA form a highly colored azo dye that is measured spectrophotometrically at $540 \mathrm{~nm}$. The median limit of detection (LOD) was $2 \mathrm{ppb}$. All analytical batches included 10\% field and laboratory blanks, duplicates, and spiked samples.

Airborne nicotine (second hand smoke; SHS) was sampled using a passive air sampler consisting of a sodium bisulfate-treated filter contained in a $37-\mathrm{mm}$ polystyrene cassette covered with a polycarbonate filter diffusion screen [11]. Nicotine content was analyzed using gas chromatography with a GC/MS. The LOD of the passive air nicotine badges was $0.005 \mathrm{ug} / \mathrm{m}^{3}$. We defined air nicotine concentrations greater than the LOD as positive for indoor SHS exposure. All methods are described in further detail in our previous work [12].

\subsection{Statistical Analysis}

Descriptive statistics were used to characterize the patient sample and the pollutant concentrations. Continuous variables were compared using Kruskal-Wallis tests. All analyses were performed using StataSE statistical software, version 12.0 (StataCorp, College Station, TX). Statistical significance was defined as $\mathrm{p}<0.05$.

\section{Results}

Ten homes were recruited and completed both visits. Half of homes used wood and/or coal for heating (Table 1). Overall PM concentrations were high (Table 2(a)). Over both seasons, median $\mathrm{PM}_{2.5}$ concentrations were $34 \mathrm{ug} / \mathrm{m}^{3}$ in all homes, $61 \mathrm{ug} / \mathrm{m}^{3}$ in homes using wood and/or coal, $10 \mathrm{ug} / \mathrm{m}^{3}$ in homes with electric heat, and $52 \mathrm{ug} / \mathrm{m}^{3}$ in homes with gas heat. In the homes using wood and/or coal for heating, median $\mathrm{PM}_{2.5}$ concentrations were $72 \mathrm{ug} / \mathrm{m}^{3}$ and $49 \mathrm{ug} / \mathrm{m}^{3}$ in August and December, respectively. Median $\mathrm{PM}_{2.5-10}$ concentrations across seasons were $15 \mathrm{ug} / \mathrm{m}^{3}$ for all homes, $18 \mathrm{ug} / \mathrm{m}^{3}$ in wood/coal homes, $9 \mathrm{ug} / \mathrm{m}^{3}$ in electric homes, and $18 \mathrm{ug} / \mathrm{m}^{3}$ in homes with gas heat. In homes using wood and/or coal, August and December median $\mathrm{PM}_{2.5-10}$ concentrations were $16 \mathrm{ug} / \mathrm{m}^{3}$ and 19 $\mathrm{ug} / \mathrm{m}^{3}$, respectively.

Table 1. Housing characteristics.

\begin{tabular}{|c|c|c|}
\hline & $\begin{array}{c}\text { August } \\
\mathrm{n}=10\end{array}$ & $\begin{array}{c}\text { December } \\
\mathrm{n}=10\end{array}$ \\
\hline \multicolumn{3}{|l|}{ Primary heating fuel $\mathbf{n}(\%)$} \\
\hline Electric & $3(30)$ & $3(30)$ \\
\hline Coal only & $1(10)$ & $1(10)$ \\
\hline Wood only & $1(10)$ & $1(10)$ \\
\hline Wood and coal & $3(30)$ & $3(30)$ \\
\hline Gas & $2(20)$ & $2(20)$ \\
\hline \multicolumn{3}{|l|}{ Cooking stove fuel n (\%) } \\
\hline Electric & $9(90)$ & $9(90)$ \\
\hline No stove & $1(10)$ & $1(10)$ \\
\hline \multicolumn{3}{|l|}{ Smoking status n (\%) } \\
\hline Smoking in home & $4(40)$ & $5(50)$ \\
\hline No smoking in home & $6(60)$ & $5(50)$ \\
\hline \multicolumn{3}{|l|}{ General condition of home $n(\%)$} \\
\hline 1-extremely poor & $3(30)$ & $3(30)$ \\
\hline 2-poor & $1(10)$ & $1(10)$ \\
\hline 3-average level of housekeeping & $2(20)$ & $2(20)$ \\
\hline 4-above average, clean & $4(40)$ & $4(40)$ \\
\hline 5-highly organized, extremely clean & 0 & 0 \\
\hline \multicolumn{3}{|l|}{ Pets in home $n(\%)$} \\
\hline None & $3(30)$ & $3(30)$ \\
\hline Dog & $7(70)$ & $7(70)$ \\
\hline Cat & $2(20)$ & $2(20)$ \\
\hline Bird & $1(10)$ & $1(10)$ \\
\hline
\end{tabular}


Table 2. (a) Pollutant concentrations: Particulate matter; (b) Pollutant concentrations: $\mathrm{NO}_{2}$ and Nicotine.

(a)

\begin{tabular}{|c|c|c|c|c|c|c|}
\hline \multicolumn{7}{|c|}{ Results by Individual Home } \\
\hline $\begin{array}{c}\text { Primary } \\
\text { heating fuel }\end{array}$ & Stove type & Smoker & $\begin{array}{c}\mathrm{PM}_{2.5}\left(\mathrm{ug} / \mathrm{m}^{3}\right) \\
\text { August }\end{array}$ & $\begin{array}{c}\mathrm{PM}_{2.5}\left(\mathrm{ug} / \mathrm{m}^{3}\right) \\
\text { December }\end{array}$ & $\begin{array}{c}\mathrm{PM}_{2.5-10}\left(\mathrm{ug} / \mathrm{m}^{3}\right) \\
\text { August }\end{array}$ & $\begin{array}{c}\mathrm{PM}_{2.5-10}\left(\mathrm{ug} / \mathrm{m}^{3}\right) \\
\text { December }\end{array}$ \\
\hline Wood + Coal & Electric & Yes & 72.4 & 119.0 & 8.2 & 14.9 \\
\hline Wood + Coal & Electric & Yes & 133.8 & 152.6 & 12.5 & 88.0 \\
\hline Coal & Electric & No & 22.9 & 15.0 & 35.1 & 18.8 \\
\hline Wood & Electric & Yes & 49.9 & 34.3 & 16.0 & 16.2 \\
\hline Wood & Electric & Yes & 111.7 & 49.2 & 47.2 & 50.5 \\
\hline Kerosene & No stove & Yes & 68.9 & 81.8 & 16.4 & 19.9 \\
\hline Propane & Electric & No & 26.4 & 34.3 & 2.2 & 26.1 \\
\hline Electric & Electric & No & 10.0 & 7.0 & 9.0 & 14.4 \\
\hline Electric & Electric & No & 11.7 & 7.7 & 5.2 & 9.3 \\
\hline Electric & Electric & No & 10.4 & 12.8 & 5.8 & 10.8 \\
\hline \multicolumn{7}{|c|}{ Results by Fuel Type Median (range) } \\
\hline All homes $(\mathrm{n}=10)$ & & & $38.1(10.0,133.8)$ & $34.3(7.0,152.6)$ & $10.7(2.2,47.2)$ & $17.5(9.3,88.0)$ \\
\hline Electric heat $(n=3)$ & & & $10.4(10.0,11.7)$ & $7.7(7.0,12.8)$ & $5.8(5.2,9.0)$ & $10.8(9.3,14.4)^{*}$ \\
\hline $\begin{array}{c}\text { Wood and/or coal } \\
\text { heat }(\mathrm{n}=5)\end{array}$ & & & $72.4(22.9,133.8)$ & $49.2(15.0,152.6)$ & $16.0(8.2,47.2)$ & $18.8(14.9,88.0)$ \\
\hline Gas heat $(\mathrm{n}=2)$ & & & $47.7(26.4,69.0)$ & $58.0(34.3,81.8)$ & $9.3(2.2,16.4)$ & $23.0(19.9,26.1)$ \\
\hline
\end{tabular}

$\mathrm{BD}=$ below limit of detection, ${ }^{*}$ Denotes significant difference in pollutant concentration between August and December (p-value < 0.05).

(b)

\begin{tabular}{|c|c|c|c|c|c|c|}
\hline \multicolumn{7}{|c|}{ Results by Individual Home } \\
\hline Primary heating fuel & Stove type & Smoker & $\begin{array}{c}\mathrm{NO}_{2} \text { (ppb) } \\
\text { August }\end{array}$ & $\begin{array}{l}\mathrm{NO}_{2} \text { (ppb) } \\
\text { December }\end{array}$ & $\begin{array}{c}\text { Nicotine }\left(u g / \mathrm{m}^{3}\right) \\
\text { August }\end{array}$ & $\begin{array}{l}\text { Nicotine }\left(\mathrm{ug} / \mathrm{m}^{3}\right) \\
\text { December }\end{array}$ \\
\hline Wood + Coal & Electric & Yes & 2.2 & 2.2 & 2.39 & 7.96 \\
\hline Wood + Coal & Electric & Yes & 11.9 & 19.0 & 41.12 & 7.34 \\
\hline Coal & Electric & No & 3.6 & 20.2 & 0.96 & 0.45 \\
\hline Wood & Electric & Yes & 4.1 & 4.0 & 7.48 & 2.47 \\
\hline Wood & Electric & Yes & 3.4 & 2.6 & 11.84 & 1.52 \\
\hline Kerosene & No stove & Yes & 2.3 & 197.4 & 6.66 & 0.73 \\
\hline Propane & Electric & No & 1.6 & 124.0 & $\mathrm{BD}$ & $\mathrm{BD}$ \\
\hline Electric & Electric & No & 0.8 & 2.0 & 0.28 & 0.10 \\
\hline Electric & Electric & No & 1.4 & 2.1 & $\mathrm{BD}$ & 0.04 \\
\hline Electric & Electric & No & 1.7 & 1.8 & 0.94 & 0.07 \\
\hline \multicolumn{7}{|c|}{ Results by Fuel Type Median (range) } \\
\hline All homes $(n=10)$ & & & $2.3(0.8,11.9)$ & $3.3(1.8,197.4)$ & $1.7(<0.01,41.1)$ & $0.6(0.01,8.0)$ \\
\hline Electric heat $(\mathrm{n}=3)$ & & & $1.4(0.8,1.7)$ & $2.0(1.8,2.1)^{*}$ & $0.3(<0.01,0.9)$ & $0.07(0.04,0.1)$ \\
\hline Wood and/or coal heat $(n=5)$ & & & $3.6(2.2,11.9)$ & $4.0(2.2,20.2)$ & $7.5(1.0,41.1)$ & $2.5(0.4,8.0)$ \\
\hline Gas heat $(n=2)$ & & & $2.0(1.6,2.3)$ & $160.7(124.0,197.4)$ & $3.33(<0.01,6.7)$ & $0.4(0.01,0.7)$ \\
\hline
\end{tabular}

$\mathrm{BD}$ = below limit of detection; " Denotes significant difference in pollutant concentration between August and December (p-value $<0.05$ ). 
Median $\mathrm{NO}_{2}$ concentrations were higher in December (3.3 ppb) than August (2.3 ppb) with concentrations most notable in homes using gas fuel during the heating season (median concentration $161 \mathrm{ppb}$ ) (Table 2(b)). Fifty percent of participants reported smoking in their homes, and eighty percent of homes in August and 90\% in December had detectable nicotine concentrations (Table 2(b)).

\section{Discussion}

We found high concentrations of indoor pollutants in our sample of homes in Central Appalachia, even during non-heating seasons. Concentrations of PM in our study homes were remarkably higher than levels reported in many US urban homes $[13,14]$. Although lower than many international settings, where biomass is used in open stoves for both cooking and heating [15-17], our sample had PM concentrations similar or high compared to other North American homes reporting regular wood and/or coal use [18-20]. For example, indoor $\mathrm{PM}_{2.5}$ concentration was less than $15 \mathrm{ug} / \mathrm{m}^{3}$ in a British Columbia population impacted by wood stoves [20]. A Rocky Mountain study evaluating the effect of woodstove replacement on indoor and ambient air quality reported a mean $\mathrm{PM}_{2.5}$ concentration of $51.2 \mathrm{ug} / \mathrm{m}^{3}$ prior to stove change out [18]. However, these studies and many other studies conducted in North American homes using wood and coal excluded smoking homes. In our population, given the high pollutant concentrations in the non-heating season and high prevalence of smoking, it is difficult to discern the relative contribution of wood/coal use and other particle-generating sources, like tobacco use, to the high PM concentrations found in this sample.

We did not find a statistically significant difference in PM concentrations between heating and non-heating seasons in homes using coal or wood for heat, but the coarse fraction of PM during the heating season was higher as compared to the non-heating season in homes using electric heat. These results were somewhat unexpected, but may represent the contribution of other non-heating particle-generating activities to PM concentrations and venting of coal/wood burning stoves to the outdoors. In addition, unmeasured differences between housing characteristics and the small sample size could partially explain the trends we observed.

Though difficult to make definitive conclusions based on the limited number of homes included in our sample, $\mathrm{NO}_{2}$ concentrations in December were strikingly high in homes using gas space heaters, and remarkably higher than in urban environments where gas stoves are the predominant $\mathrm{NO}_{2}$ source [21,22]. For example, the concentration of indoor $\mathrm{NO}_{2}$ in Baltimore homes using gas stoves for cooking was $33.1 \mathrm{ppb}$, and similar results were found in Connecticut homes with gas stoves as the pri- mary source of $\mathrm{NO}_{2}$ [21,22]. In the Appalachia sample, mechanical characteristics of the space heaters, lack of sufficient ventilation, and smaller home size may contribute to the high concentration of $\mathrm{NO}_{2}$ in these homes. Additional investigation is needed to characterize the impact of gas heaters and other combustion sources used for heating on indoor $\mathrm{NO}_{2}$ concentrations.

To our knowledge, this is one of only two studies to report direct measurements of indoor air quality in rural homes in Central Appalachia [19]. Our results show the feasibility of indoor air monitoring in Central Appalachia. Furthermore, though our results do not definitively show an increase in pollutant burden during the heating season, they highlight the overall poor indoor air quality and high $\mathrm{PM}$ and $\mathrm{NO}_{2}$ concentrations found in homes in this rural community. Given the known adverse health effects of pollutant exposure, further study is needed to investigate the contribution of poor indoor air quality associated with indoor combustion materials to negative public health outcomes seen in Appalachia, and to develop feasible interventions to help reduce the pollutant burden in the indoor environment.

\section{REFERENCES}

[1] World Resources Institute, United Nations Environment Programme, United Nations Development Programme and World Bank, "1998-1999 World Resources: A Guide to the Global Environment,” Oxford University Press, Oxford, 1998.

[2] N. Bruce, R. Rogelio Perez-Padilla and R. Albalak, "Indoor Air Pollution in Developing Countries: A Major Environmental and Public Health Challenge," Bulletin of the World Health Organization, Vol. 78, No. 9, 2000, pp. 1078-1092.

[3] J. E. Houck, P. E. Tiegs, R. C. McCrillis, C. Keithley and J. Crouch, "Air Emissions from Residential Heating: The Wood Heating Option Put into Environmental Perspective," The Proceedings of a US EPA and Air Waste Management Association Conference: Emission Inventory: Living in a Global Environment, Vol. 1, 1998, pp. 373384.

[4] H. D. Hosgood, P. Boffetta, et al., "In-Home Coal and Wood Use and Lung Cancer Risk: A Pooled Analysis of the International Lung Cancer Consortium,” Environmental Health Perspectives, Vol. 118, No. 12, 2010, pp. 17431747. doi:10.1289/ehp.1002217

[5] A. V. Ramanakumar, M. E. Parent and J. Siemiatycki, "Risk of Lung Cancer from Residential Heating and Cooking Fuels in Montreal, Canada," American Journal of Epidemiology, Vol. 165, No. 6, 2007, pp. 634-642. doi:10.1093/aje/kwk117

[6] S. S. Salvi and P. J. Barnes, "Chronic Obstructive Pulmonary Disease in Non-Smokers,” Lancet, Vol. 374, No. 9691, 2009, pp. 733-743. doi:10.1016/S0140-6736(09)61303-9

[7] A. C. Barry, D. M. Mannino, C. Hopenhayn and H. Bush, 
"Exposure to Indoor Biomass Fuel Pollutants and Asthma Prevalence in Southeastern Kentucky: Results from the Burden of Lung Disease (BOLD) Study," Journal of Asthma, Vol. 47, No. 7, 2010, pp. 735-741. doi:10.3109/02770903.2010.485661

[8] M. L. Clark, S. J. Reynolds, J. B. Burch, S. Conway, A. M. Bachand and J. L. Peel, "Indoor Air Pollution, Cookstove Quality, and Housing Characteristics in Two Honduran Communities," Environmental Research, Vol. 110, No. 1, 2010, pp. 12-18. doi:10.1016/j.envres.2009.10.008

[9] M. Ezzati, H. Saleh and D. M. Kammen, "The Contributions of Emissions and Spatial Microenvironments to Exposure to Indoor Air Pollution from Biomass Combustion in Kenya,” Environmental Health Perspectives, Vol. 108, No. 9, 2000, pp. 833-839. doi:10.1289/ehp.00108833

[10] M. Zuk, L. Rojas, S. Blanco, et al., "The Impact of Improved Wood-Burning Stoves on Fine Particulate Matter Concentrations in Rural Mexican Homes," Journal of Exposure Science and Environmental Epidemiology, Vol. 17, No. 3, 2007. pp. 224-232. doi:10.1038/sj.jes.7500499

[11] S. K. Hammond and B. P. Leaderer, "A Diffusion Monitor to Measure Exposure to Passive Smoking," Environmental Science \& Technology, Vol. 21, No. 5, 1987, pp. 494-497. doi:10.1021/es00159a012

[12] G. B. Diette, N. N. Hansel, T. J. Buckley, et al., "Home Indoor Pollutant Exposures among Inner-City Children with and without Asthma," Environmental Health Perspectives, Vol. 115, No. 11, 2007, pp. 1665-1669. doi:10.1289/ehp.10088

[13] D. Brugge, J. Vallarino, L. Ascolillo, et al., "Comparison of Multiple Environmental Factors for Asthmatic Children in Public Housing,” Indoor Air, Vol. 13, No. 1, 2003, pp. 18-27. doi:10.1034/j.1600-0668.2003.01130.x

[14] M. C. McCormack, P. N. Breysse, N. N. Hansel, et al., "Common Household Activities are Associated with Elevated Particulate Matter Concentrations in Bedrooms of Inner-City Baltimore Pre-School Children," Environmental Research, Vol. 106, No. 2, 2008, pp. 148-155. doi:10.1016/j.envres.2007.08.012

[15] A. A. Cynthia, R. D. Edwards, M. Johnson, et al., "Reduction in Personal Exposures to Particulate Matter and Carbon Monoxide as a Result of the Installation of a Pat- sari Improved Cook Stove in Michoacan Mexico,” Indoor Air, Vol. 18, No. 2, 2008, pp. 93-105. doi:10.1111/j.1600-0668.2007.00509.x

[16] O. P. Kurmi, G. S. Devereux, W. C. Smith, et al., "Reduced Lung Function Due to Biomass Smoke Exposure in Young Adults in Rural Nepal," European Respiratory Journal, Vol. 41, No. 1, 2012, pp. 25-30. doi:10.1183/09031936.00220511

[17] J. Regalado, R. Pérez-Padilla, R. Sansores, et al., “The Effect of Biomass Burning on Respiratory Symptoms and Lung Function in Rural Mexican Women,” American Journal of Respiratory and Critical Care Medicine, Vol. 174, No. 8, 2006, pp. 901-905. doi:10.1164/rccm.200503-4790C

[18] T. J. Ward, C. Palmer, M. Bergauff, et al., "Results of a Residential Indoor $\mathrm{PM}_{2.5}$ Sampling Program Before and after a Woodstove Changeout,” Indoor Air, Vol. 18, No. 5, 2008, pp. 408-415. doi:10.1111/j.1600-0668.2008.00541.x

[19] A. R. Hawthorne, R. B. Gammage and C. S. Dudney, “An Indoor Air Quality Study of 40 East Tennessee Homes,” Environment International, Vol. 12, No. 1-4, 1986, pp. 221-239. doi:10.1016/0160-4120(86)90034-6

[20] R. W. Allen, C. Carlsten, B. Karlen, et al., “An Air Filter Intervention Study of Endothelial Function among Healthy Adults in a Woodsmoke-Impacted Community," American Journal of Respiratory and Critical Care Medicine, Vol. 183, No. 9, 2011, pp. 1222-1230. doi:10.1164/rccm.201010-15720C

[21] N. N. Hansel, P. N. Breysse, M. C. McCormack, et al., "A Longitudinal Study of Indoor Nitrogen Dioxide Levels and Respiratory Symptoms in Inner-City Children with Asthma," Environmental Health Perspectives, Vol. 116, No. 10, 2008, pp. 1428-1432. doi:10.1289/ehp.11349

[22] K. Belanger, J. F. Gent, E. W. Triche, et al., “Association of Indoor Nitrogen Dioxide Exposure with Respiratory Symptoms in Children with Asthma," American Journal of Respiratory and Critical Care Medicine, Vol. 173, No. 3, 2006, pp. 297-303. doi:10.1164/rccm.200408-11230C 